\title{
Vývoj a chápaní pojmu „experience“" v teorii zkušenostního učení Johna Deweyho Pavel Votava
}

\begin{abstract}
Abstrakt
Cílem článku je ukázat význam a užití pojmu „experience“ v různých oblastech v kontextu teorie zkušenostního učení Johna Deweyho. V úvodu čtenáři je nejprve představen americký filosof a pedagog John Dewey a okolnosti vedoucí ke vzniku pragmatické pedagogiky. V každé kapitole autor popisuje vývoj a chápání pojmu „experience" v souvislosti s konkrétní Deweyho publikací související s jeho teorií zkušenostního učení. V první kapitole se jedná o knihu Democracy and Education, ve druhé Experience and Nature, ve třetí Art as Experience a v poslední Experience and Education. $V$ závěru autor shrnuje zjištěné poznatky.
\end{abstract}

Klíčová slova: John Dewey, zkušenost, zkušenostní učení, učení děláním, pragmatická pedagogika

\section{Úvod}

John Dewey (1859-1952) byl jedním z nejvlivnějších amerických filosofů první poloviny 20. století. Jeho největší přínos můžeme sledovat především na poli pedagogických věd. Po vystudování Vermontské univerzity sám na několika vysokých školách vyučoval. Je považován za významnou osobnost pragmatické pedagogiky, která na přelomu 19. a 20. století znamenala výraznou změnu v chápání žáka jako subjektu edukace. Dewey se orientací na zájmy a zkušenosti žáků výrazně zasadil o rozvoj pedocentrismu, který je podle něj „lékem“ na metody tradiční pedagogiky. ${ }^{1}$

Dewey a další zastánci pragmatické pedagogiky tvrdí, že v tradičním pojetí edukace je na žáka nahlíženo jako na objekt edukace, který je odsouzený do pasivní role a vedený učitelem jako nejvyšší svrchovanou autoritou. Autorita učitele je upevňována neustálým dozorem, tresty (výjimečně i tresty tělesnými), zákazy a odnímáním svobody. To logicky vede k potlačení kreativity a iniciativy žáků, kteří následně trpí až přehnaným formalismem a důrazem na teoretickou znalost obsahu vzdělávání s minimálním uplatněním osvojených znalostí v praxi. Tradiční pedagogika se systematicky vyhýbá odpovědnosti za hledání vhodných podmínek k získávání zkušeností $\mathrm{k}$ dalšímu růstu žáků. Školní prostředí lavic, tabulí a malého školního dvorku je v tradičním pojetí pokládáno za dostačující. V tradiční pedagogice není žádná zmínka, že by měl učitel iniciovat uspořádání podmínek lokálního prostředí (fyzické, historické, ekonomické, profesní a další) za

1 Srov. Miroslav CIPRO, Galerie světových pedagogů. Dvacáté století, Praha: M. Cipro, 2002, s. 5. 
účelem jejich zužitkování jako výchovných zdrojů. ${ }^{2}$

Dewey argumentuje, že oproti tradičnímu pojetí výchovy je pragmatické, resp. progresivní pojetí výchovy nastavené proti přehnanému formalismu a nesouhlasí s důrazem na striktní disciplínu, pasivní učení a „tupý dril“. ${ }^{3}$ Dewey před vnější disciplínou upřednostňuje volnou aktivitu a místo drilového učení z textů a od vyučujících prosazuje učení skrze zážitky. ${ }^{4}$ Člověk tak na základně experimentace, cestou pokusů a omylů dochází k různým myšlenkám, názorům a zákonům, které mu pomáhají orientovat se v uvedené situaci. ${ }^{5}$ Deweyho výchovný systém je založený na nutnosti spojení výchovy a zkušeností, které musíme brát neustále v potaz. Tento náročný požadavek na edukátora je podle Deweyho důvodem, proč je pragmatické pojetí vzdělávání obtížnější než tradiční vzdělávací systém. ${ }^{6}$

Výzkumnou otázku si pokládám ve vztahu k Deweyho teorii zkušenostního učení, kde zdůrazňuje nezbytné propojení teorie s praxí. Jak se vyvíjelo chápaní pojmu „experience“v publikacích zahrnujících poznatky k teorii zkušenostního učení? Mezi jeho klíčové publikace, které zahrnují poznatky k teorii zkušenostního učení a pojmu „experience“ patří Experience and Education (1938), Art as Experience (1934), Experience and Nature (1925), Democracy and Education (1916). ${ }^{7}$

\section{Pojem „experience“v publikaci Democracy and Education}

Kniha Democracy and Education, publikovaná v roce 1916, je považovaná za majoritní a nejznámější dílo Johna Deweyho. Většinou filosofů a pedagogů je kniha považována za stěžejní text pragmatické pedagogiky. Dewey zde kritizuje zastaralé a neefektivní herbartovské školy a shrnuje veškeré své poznatky o výchově. Chybou školství je př́lišné soustředění se na budoucnost a přípravu na dospělost. Dewey prosazuje zájmy dítěte, především plné prožívání jeho dětství. Kvalita školní výchovy by se měla posuzovat na základě toho, jakou vyvolává u žáků chut’ se zdokonalovat a rozvíjet, a jak je úspěšná v poskytování podmínek, které touhu po vzrůstu převedou ve skutečné konání. Dewey také zdůrazňuje nezastupitelnou roli jedince při participaci a řešení problémů společnosti za účelem rozvíjení demokratických hodnot.

Dewey zdůrazňuje tvárnost (plasticity) jako přizpůsobivost nezralé bytosti k růstu. Avšak nemá tím na mysli schopnost přijímat změnu podle vnějšího tlaku. Jde ve své podstatě o učení se ze zkušenosti, schopnost uchovat z jednotlivé zkušenosti něco, co bude prospěšné, až bude jedinec čelit potížím v některé z pozdějších situací. To znamená schopnost modifikovat jednání na základě dřivější zkušenosti a schopnost rozvíjet dispozice (dispositions), protože bez nich není možné si osvojovat návyky (habits). ${ }^{8}$

Návyk je především jistou formou dovednosti či účinnosti v jednání. Návyk znamená schopnost používat přirozených podmínek jako prostředku k jistým cílům. Výchova se často definuje jako osvojování návyků vedoucích k přizpůsobení se jedince svému prostředí. Přičemž slovo „přizpůsobuje se“ je použito v aktivním smyslu kontroly a ovládání prostředků k dosažení cílů. Pokud chápeme návyk jen jako změnu, jež byla vyvolána v organismu, a ignorujeme přitom fakt, že tato změna spočívá ve schopnosti ovlivňovat následující změny v prostředí, dospějeme $\mathrm{k}$ tomu, že

\footnotetext{
Srov. John DEWEY, Experience and Education, New York: Kappa Delta Pi, 1938, s. 40-41.

Srov. František SINGULE, Americká pragmatická pedagogika, Praha: Státní pedagogické nakladatelství, 1990, s. 23.

Srov. DEWEY, Experience and Education..., s. 19.

Srov. SINGULE, Americká..., s. 29.

Srov. DEWEY, Experience and Education..., s. 40.

Srov. tamtéž, s. 7.

Srov. John DEWEY, Democracy and Education. An Introduction to The Philosophy of Education, New York: The Macmillan Company, 1916, s. 52-53.
} 
budeme chápat „přizpůsobení se“ jako konformitu s prostředím. Avšak Dewey má na mysli př̀izpůsobení jedince vnějším podmínkám. ${ }^{9}$

Podle Deweyho je výchova žáků neustálou reorganizací či rekonstrukcí zkušenosti, která obohacuje její smysl a zároveň zvyšuje schopnost usměrnění následujících zkušeností. ${ }^{10}$ Získání zkušenosti díky aktivnímu procesu zabere určitý čas. Následující zkušenost doplňuje zkušenost již získanou a objasňuje v ní obsažené vztahy. Pozdější činnost tak upevňuje a doplňuje smysl dřivější činnosti. ${ }^{11}$

Zkušenost ve své podstatě v sobě zahrnuje kombinaci aktivních a pasivních prvků. Z aktivního hlediska je zkušenost „pokoušením se“ (trying), respektive experimentováním. Pasivní hledisko je „podstoupením“ (undergoing). Získáme-li s nějakou věcí zkušenost, znamená to, že jsme na věc působili, nějakým způsobem jsme s ní pracovali, a následně shledáváme výsledky a důsledky naší činnosti. ${ }^{12}$ Pouhá činnost však ještě nevede ke zkušenosti. Často nás jen rozptyluje a odčerpává naše síly. Zkušenost chápaná jako pokoušení se znamená změnu, ale pokud není tato změna vědomě spojena $s$ důsledky $z$ ní plynoucími, je jen pouhým méněcenným přechodem. Avšak pokračuje-li se v činnosti až do podstoupení důsledků, tj. až do okamžiku, kdy se změna dosažená činností odrazí ve změně, která nastane v konkrétním jedinci, pak tento pravý sled činností dostane význam. To Dewey ilustruje na př́kladu s dítětem, které chce strčit ruku do ohně. Když dítě strčí ruku do ohně, ještě to není zkušenost. Zkušeností se to stane, jestliže je tento pohyb spojený s bolestí, kterou dítě podstoupí jako důsledek. Od tohoto okamžiku strčení ruky do ohně znamená pro dítě spálení se. ${ }^{13}$

Termínem učit se ze zkušeností (learn from experience) Dewey rozumí vytváření spojení jak zpětně, tak i do budoucnosti mezi naším působením na věci a příjemnými či nepříjemnými zážitky, které z toho pro nás plynou. Za takových podmínek se činnost stává pokusem. Je to experiment s okolním světem, abychom zjistili, jaký je. Tyto zážitky se stanou poučením vedoucím k objevu propojení mezi věcmi. ${ }^{14}$

Dewey dále popisuje obecné myšlenkové kroky při vytváření zkušenosti:

1. Spletitost, zmatenost a pochyby vyplývající ze situace, kterou neznáme.

2. Dohady a pokusy interpretovat známé prvky, o nichž si myslíme, že povedou k jistým důsledkům.

3. Pečlivé zkoumání, tj. vyšetření, probádání a rozbor všech úvah, jež by mohly vymezit a objasnit daný problém.

4. Vypracování obecné hypotézy, kterou postupně zpřesňujeme a propracováváme tím, že ji podepíráme dalšími fakty.

5. Vytvořenou hypotézu použijeme jako plán činnosti k řešení daného stavu věcí. ${ }^{15}$

\section{Pojem „experience“v publikaci Experience and Nature}

Jak už název knihy napovídá, stěžejní problematika je zaměřena na vzájemné vztahy zkušeností a prrírody a je zde patrná autorova snaha přimět čtenáře nahlížet na tyto fenomény novým způsobem. Na základě empirického naturalismu Dewey analyzuje zkušenosti a zkoumá jejich vliv

9 Srov. tamtéž, s. 54-55.

10 Srov. tamtéž, s. 89-90.

11 Srov. tamtéž, s. 91-92.

12 Srov. tamtéž, s. 163.

13 Srov. tamtéž.

14 Srov. tamtéž, s. 164.

15 Srov. tamtéž, s. 176. 
na aktuální tendence v chování jedince. Dewey v knize rozebírá i témata z oblasti epistemologie, metafyziky a filosofie. V knize však nalezneme i pojednání o umění, morálce a hodnotách. Dewey se zabývá otázkou vztahu mezi zkušeností (experience) a př́rodou (nature). Tvrdí, že zkušenosti mohou být prostředkem k odhalení přírodních skutečností. Zkušenost není „závojem“, který člověku zahaluje hlubší významy přírody, naopak díky zkušenostem máme možnost do nich proniknout a lépe je chápat. Dewey zdo̊razňuje „historii př́rody“ a kontinuitu změn plynoucích od počátku do konce. Za výsledky zážitků v kooperaci s přírodou můžeme považovat nástroje, techniky a mechanismy, které lidé potřebují ke svému životu. ${ }^{16}$ Například geolog žijící v dnešní době nám může podat informace o skutečnostech, které se staly dávno před tím, než se narodil, a dokonce ještě miliony let před tím, než se na Zemi objevili první lidé. Svou práci začne studiem „zkušenostních materiálư (material of experience). Zkoumá složení zemské kůry, nerostů a hornin. Získané poznatky konzultuje s kolegy jiných oborů, aby získaná data byla co nejpřesnější. Z výsledných dat pak dokáže zrekonstruovat události, které se staly v minulosti. ${ }^{17}$

Dewey popisuje zážitky (actual experience) jako fenomény představující řadu změn, jejichž cílová hodnota je konzumace a naplnění. Jedinec má tendenci je opakovat a učinit je stabilními. Je zřejmé, že se jedinec podílí na vzniku nových situací a zážitků, a způsob jakým jedná, je ovlivněn jeho předchozími zkušenostmi, které mají dopad i na jeho současné chování. Ačkoliv Dewey př́ímo neodkazuje na Darwinovu evoluční teorii, poukazuje na skutečnost, že každá forma života v nižších organismech zanechá stopu v evolučně vyšších a dokonalejších organismech včetně nás lidí. Příkladem může být například sací či úchopový reflex u kojenců nebo pud sebezáchovy u dospělé populace. ${ }^{18}$ Dewey přemýšlí o rozdělení zkušenosti na svrchovanou, absolutní (absolute experience) a na lidskou zkušenost (human experience). Absolutní zkušenost by měla představovat stabilitu i nestabilitu celého světa a všechny jeho zkušenosti. Tato zkušenost je jako jediná neustále perfektní. Na rozdíl od lidské zkušenosti, která je dočasná, plná chyb, omylů, konfliktů a rozporů. ${ }^{19}$

\section{Pojem „experience“ v publikaci Art as Experience}

Kniha Art as Experience, publikovaná v roce 1934, měla značný vliv v oblasti estetiky a filosofie umění na konci první poloviny 20. století. Zabývá se teorií estetické zkušenosti (aesthetic experience). Tato teorie je snahou o pochopení, co je důležité a charakteristické v umění a procesu jeho utváření v celé jeho celistvosti. O zkušenosti hovoří jako o „produktu“, který vzniká v nepřetržité kumulující se interakci jedince se světem. Pomocí uměleckých děl, kam vkládáme naše zkušenosti, umožňujeme lidem jejich sdílení. Svět umění je často identifikován s existencí budov, knih, maleb či soch odděleně od lidské zkušenosti, přitom je evidentní, že jde o důsledky aktuálních životních zkušeností. Úkolem estetiky je obnovit vzájemný vztah mezi kultivovanými a vytř́ibenými zkušenostmi, jako jsou podle Deweyho umělecká díla, a zkušenostmi z každodenního života. Dewey uměleckým dílem rozumí jak výsledek, tak obsah zkušenosti. ${ }^{20}$

Každý žijící jedinec, který se vědomě či nevědomě snaží adaptovat v prostředí, kde žije, se zároveň snaží dosáhnout rovnováhy a harmonie s tímto prostředím. Rovnováha je výsledkem dynamického vyřešení vzniklého napětí. Estetická zkušenost zahrnuje tři podstatné faktory, kterými jsou

16 Srov. John DEWEY, Experience and Nature, Chicago: Open Court Publishing Company, 1929, s. 1a.

17 Srov. DEWEY, Experience and Nature..., s. 3a-4a.

18 Srov. tamtéž, s. 246-247.

19 Srov. tamtéž, s. 59-60.

20 Srov. John DEWEY, Art as Experience, New York: Penguin group, 1934, s. 3. 
akce, pocit a smysl. Estetická zkušenost by nenastala ve světě, který by byl už „hotový“, beze změn, nebot by nebylo možné do takto hotového světa vložit žádné nové myšlenky, nápady a řešení nově vzniklých problémů. Přechod od narušení ke znovuzískání harmonie poskytuje člověku nejintenzivnější zážitek. Pocit štěstí je výsledkem hlubokého naplnění, v němž se člověk jako celistvá bytost přizpůsobila životnímu prostředí. ${ }^{21}$

Koncept estetických zkušeností je výzvou pro filozofii, protože se může svobodně rozvíjet stejně jako zkušenost. Filozofové tedy musí zkoumat estetiku, aby zjistili význam zkušeností. Estetické teorie se snaží vysvětlit estetické zkušenosti. Estetické teorie mohou být klasifikovány podle jednotlivých prvků, které zdůrazňují. ${ }^{22}$ Protože nám umění vycházející z estetických zkušeností často dává pocit většího porozumění přírodě a lidem, někteří filozofové umění viděli jako druh vědění, který je nadřazen vědě. ${ }^{23}$

Dewey se domnívá, že zdroje estetické zkušenosti se nachází také u zviŕata. Zviŕăata často dosahují jednoty zkušeností, které lidé ztrácejí v „rozkouskovaném“ pracovním životě. Živé zvíre žije př́itomností všemi svými smysly. Spojuje minulost i budoucnost v současném jednání. Podobně se i v člověku nacházejí estetické zkušenosti, které mohou být jednotné, pokud bude velmi ostražitý k okolnímu prostředí. Jeho ostražitost je dvojí akcí - předvídáním a př́pravou na budoucnost. Lidé své smysly nevyužívají pouze k uložení informací, ale především nás naše smysly nutí myslet a připravit nás $\mathrm{k}$ jednání. Zkušenost je ukazatelem úrovně aktivního zabývání se světem. Poznání světa a sebe sama je podle Deweyho počátek umění. ${ }^{24}$

Dewey se dále vrací k základnímu pojmu teorie zkušenostního učení a tím je pojem zkušenost. Zkušeností může být například přetváření materiálu do konkrétního výrobku, hraní šachů, psaní knihy či vyřešení určitého problému. Taková zkušenost je celistvá, má svoji individuální kvalitu a svébytnost. Zkušenosti získáváme pravidelně, protože interakce jedince s jeho životními podmínkami jsou neustálým procesem. Oproti tomu počáteční zážitek (inchoate experience) je chápán jako teprve začínající a nevyvinutá zkušenost. Jedinec je $\mathrm{v}$ této fázi ještě rozptýlený a je pravděpodobné, že nedokončí cíl, který chce splnit. Je to pouze „zárodeční zkušenost“, která není ukončená. Zkušenost je také odrazem jiných zkušeností, které v sobě obsahují individualizační kvalitu. Dewey věří, že jeho teorie zkušenostního učení je v souladu s použitím v každodenním životě, přestože je to v rozporu s tím, jak o zkušenostním učení hovoří jiní filosofové. Dewey chápe život jako př́běh se svými vlastními zápletkami, počátky, závěry a dynamikou. Každý život má jedinečnou kvalitu. ${ }^{25}$

Ve zkušenosti jako celku se každá její dílčí část volně šiří do toho, co následuje, a zároveň v sobě nese předcházející obsah. Tyto části zapadají do dlouhotrvajícího celku. Ve zkušenostech nejsou žádná prázdná místa či mechanická spojení. Existují pouze pauzy, „odpočinková místa“, shrnující dosavadní proces ukládání zážitků ve zkušenosti a zabraňující rozptýlení či ztrátě zažitých informací. ${ }^{26}$ Dewey tvrdí, že každá celistvá zkušenost je ukotvena, resp. usazena a zařazena do zkušenostní struktury jedince. Toho lze dosáhnout pomocí zážitků, které produkují energii. Energie je podle Deweyho „hybnou silou“ či aktivizujícím potenciálem zážitku, který si jedinec transformuje ve zkušenost. Energie však může způsobit chaos a konflikty. I když je někdy bolestivá, je znakem vývoje zkušenosti a součástí prožitého zážitku. ${ }^{27}$

\footnotetext{
Srov. tamtéž, s. 16-17.

Srov. tamtéž, s. 274-275.

Srov. DEWEY, Art..., s. 288-289.

Srov. tamtéž, s. 19

Srov. tamtéž, s. 35.

Srov. tamtéž, s. 36.

Srov. tamtéž, s. 41.
} 
Každá zkušenost musí splňovat dvě základní podmínky, bez kterých by nemohla existovat:

1. Zkušenost je výsledkem interakce mezi jedincem a konkrétním okolím, kde jedinec žije, tj. bez interakce s okolím není možné získat zkušenost.

2. Zkušenost má svoji strukturu, která obsahuje vztahy. Rozsah a obsah vztahů jsou ukazatelem významu zkušenosti. Pokud zážitek nebude zařazen do stávajících zkušenostních struktur, nebude dávat jedinci význam a smysl. ${ }^{28}$

Umělecká díla jsou důležitým př́kladem zkušeností. Zde jsou jednotlivé prvky obsažené v těchto dílech spojeny do jednoty. Jednota zkušenosti, která není výlučně emocionální, praktická ani intelektuální, je určena jediným všudypř́itomným stavem. Ale žádná zkušenost nemá jednotu bez estetické kvality. V estetických zkušenostech existuje zájem o spojení mezi každým zážitkem současným a předcházejícím. Neestetické zkušenosti se nachází mezi dvěma póly. Prvním je jejich volná posloupnost, která nezačíná ani nekončí na žádném konkrétním místě. Druhým je jejich omezení v mechanickém spojení dílčích částí. ${ }^{29}$

\section{Pojem „experience“ v publikaci Experience and Education}

Kniha Experience and Education, vydaná v roce 1938, je v porovnání s ostatními Deweyho díly nejvýznamnější pro oblast Deweyho filosofie výchovy. V první polovině 20 . století to byl velmi aktuální příspěvek pro americké školství, které chápalo pragmatické pojetí výchovy jako „novou výchovu“. ${ }^{30} \mathrm{~V}$ knize proto nacházíme analýzu tradiční i pragmatické edukace. Autor ovšem zdůrazňuje, že hodnoty žádného z těchto proudů nejsou samy o sobě dostatečné. Oba výchovné systémy jsou z hlediska teorie výchovy klíčové. ${ }^{31}$

Dewey zdůvodňuje potřebu teorie zkušenostního učení pro současnou pedagogiku. Pro pochopení vztahu mezi edukací a osobními zážitky musíme pochopit, co je to zkušenost (experience). Přesvědčení, že pravá výchova přichází skrze zážitky, neznamená, že všechny zážitky jsou pravé, skutečné nebo stejně výchovné. Proto zkušenosti získané z takových zážitků nelze chápat totožně s výchovou. Některé zážitky jsou needukativní a jako takové zadržují nebo zkreslují růst dalších pokročilejších zážitků. Mohou vyvolat bezohlednost či produkovat nedostatek citlivosti. Také mohou omezit možnosti získání bohatších zkušeností v budoucnosti. Podle Deweyho by výchovný zážitek měl být bezprostředně radostný a př́ijemný a měl by podpořit utváření nelhostejných a neukotvených postojů, protože tyto postoje a stanoviska poté operují v utváření následujících zkušeností. ${ }^{32}$

Zážitky mohou být odděleny jeden od druhého. I když každý je přijatelný nebo dokonce sám o sobě vzrušující, nejsou jeden ke druhému kumulativně spojeny. Energie z těchto zážitků je poté promrhaná či rozházená a jedinec se stává roztržitým. Každý zážitek by měl být živý, svěží a zajímavý, avšak jejich nesouvislosti mohou uměle generovat rozptyl a dezintegraci způsobů chování. Následkem takové formace těchto návyků je pak i neschopnost ovládat budoucí zkušenosti. ${ }^{33}$ Dewey dále upozorňuje na defektivní a špatný charakter zážitků z hlediska spojení s dalšími zkušenostmi. Záleží na kvalitě zkušenosti, která má dva aspekty - přijetí nebo odmítnutí a vliv zážitků. Za tento vliv je podle Deweyho zodpovědný edukátor. Jeho úkolem je navodit takový

\footnotetext{
Srov. tamtéž, s. 44.

Srov. tamtéž, s. 36-40.

Srov. DEWEY, Experience and Education..., s. 9.

Srov. tamtéž, s. 10.

Srov. tamtéž, s. 25-26.

Srov. tamtéž, s. 26.
} 
druh zážitků, které pokud nejsou studentem odmítnuty, ale donutí ho zapojit se do aktivit, potom okamžitě povýší k získání žádoucích budoucích zkušeností. Nezávisle na našem přání nebo záměru pokračuje existence každé zkušenosti $\mathrm{v}$ dalších zkušenostech získaných později. Ústředním problémem edukace založené na zkušenostech je výběr takového druhu současných prožitků, které budou žít plodně a kreativně v následujících zkušenostech. ${ }^{34}$

Dále Dewey rozebírá kritéria zkušenosti, začínající rozborem pojmu zkušenostní kontinuum (experience continuum). Tímto pojmem Dewey rozumí princip, na jehož základě na sebe zkušenosti neustále navazují. Každá zkušenost je ovlivněna předchozí zkušeností a zároveň modifikuje kvalitu zkušenosti, která bude následovat. ${ }^{35}$ Např́klad i výchovný proces dětí se vyznačuje vývojem, tj. aktivním principem růstu. Vývoj nebo růst nejen fyzický, ale také intelektový a morální je jedním z př́íladů principu zkušenostního kontinua. Důležitá je specifikace, v jakém směru růst probíhá. ${ }^{36}$

V každé snaze jedince o dosažení určitého cíle se rozlišuje, které zkušenosti jsou cenné pro výchovu a které nikoliv. Podle Deweyho je to základní kritérium zkušenosti. Zkušenosti působí kladně nebo záporně na postoje člověka, kterému pomáhají posoudit kvalitu dalších zážitků vyzdvižením jistých preferencí a averzí a usnadňují nebo znesnadňují jednání. ${ }^{37}$

Každá zkušenost ovlivňuje na určitém stupni objektivní podmínky, při kterých jedinec získá další zkušenosti. Dewey to ilustruje na příkladu dítěte, které, když se učí mluvit, získává novou dovednost a novou potřebu. Ale zároveň si rozšírí také vnější podmínky následujícího učení. Podobně si otevírá nové možnosti, když se učí číst. Dalším příkladem může být rozhodnutí člověka pro určité povolání. Stane-li se někdo právníkem, lékařem či učitelem, nutně si tím určí prostředí, ve kterém se bude v budoucnu pohybovat a jednat. Tím zvýší svoji citlivost a vnímavost $\mathrm{k}$ jistým podmínkám svého oboru a stane se relativně imunním $\mathrm{k}$ věcem, které by ho stimulovaly, kdyby se rozhodl pro jiné povolání. ${ }^{38}$ Nicméně pokud zážitek probouzí zvědavost, posiluje iniciativu a nastavuje zájmy a potřeby, které jsou dostatečně intenzivní k přenesení člověka přes „mrtvá místa“, tj. místa, kde se jedinec ve svém vývoji zasekl. Každá zkušenost je hybná síla s určitou hodnotou. Její hodnotu Dewey posuzuje např́klad podle toho, jestli je schopná přenést jedince přes „mrtvá místa" a umožnit mu další rozvoj. ${ }^{39}$ Co se člověk naučil jako znalost a schopnost v jedné situaci, může použít jako nástroj k porozumění a účinnějšímu řešení následujících situací. Aby se z člověka stala „celistvá“ osobnost, je nezbytné, aby po sobě jdoucí zkušenosti jedince byly vzájemně integrovány a zapadly do jeho celkové zkušenostní struktury. $V$ opačném př́ípadě by měl jedinec problémy se socializací ve společnosti, kde žije, nebo by dokonce došlo i k některým poruchám osobnosti. ${ }^{40}$

\section{Závěrem}

Při odpovědi na dílčí výzkumnou otázku, jak se v Deweyho publikacích vyvíjelo chápání pojmu „experience“ $v$ souvislosti s teorií zkušenostního učení, je potřeba poznamenat, že Dewey na svojí teorii nepracoval systematicky chronologicky, nýbrž každé dílo vneslo do jeho teorie nové prvky v jiném zaměření. $\mathrm{V}$ českém prostředí chápeme pojem „experience“ nejčastěji jako prožitek,

34 Srov. tamtéž, s. $27-28$

35 Srov. tamtéž, s. 35.

36 Srov. tamtéž, s. 36.

37 Srov. tamtéž, s. 34-35.

38 Srov. DEWEY, Experience and Education..., s. 37.

39 Srov. tamtéž, s. 38.

40 Srov. tamtéž, s. 44-45. 
zážitek či zkušenost. Prožitek je konkrétní děj, který člověk vnímá v konkrétním čase a místě a který se vzápětí proměňuje do podoby zážitku. Zážitek je pamětová stopa vázaná na prožitek. Vzniká víceméně automaticky, jeho síla a hloubka je závislá na síle a hloubce předchozího prožívání, které se zase odvíjí od praktického významu prožívané skutečnosti, od zájmů, potřeb a dosavadní zkušenosti účastníka. To, co má pro konkrétního člověka větší praktickou hodnotu, tedy přirozeně generuje silnější prožitky a zážitky. ${ }^{41}$ Zkušenost je trvalá podoba prožité události, jejiž výsledky jsou jedincem uplatnitelné i v jiných situacích. ${ }^{42}$

V publikacích Johna Deweyho jsem se však s takovým rozlišením jednotlivých pojmů nesetkal. Výjimečně Dewey použil pojmy „inchoate experience“ a „actual experience“. Prvním pojmem rozumí počáteční, začínající a nevyvinutou zkušenost, tj. Deweyho charakteristika nejvíce odpovídá výše zmíněnému pojmu prožitek. Druhým pojmem „actual experience“ Dewey označuje změ$\mathrm{nu}$, jejíz cílovou hodnotou je transformace $\mathrm{k}$ naplnění zkušenosti. Za výsledky těchto fenoménů v součinnosti s př́rodními podmínkami můžeme považovat prostředky, techniky a mechanismy (tj. zkušenosti), které lidé potřebují ke svému životu. Nejvíce tedy charakteristika odpovídá výše uvedenému pojmu zážitek.

Deweyho teorie zkušenostního učení se řídí základním principem kontinuity zkušeností. To znamená, že každá zkušenost na sebe navazuje, následná zkušenost modifikuje předchozí zkušenosti a modifikuje či rekonstruuje současnou zkušenostní strukturu jedince. Zkušenosti obsažené ve zkušenostní struktuře jedince pak mají vliv na výběr jedincových prožitků a na prostředí, ve kterém se bude prožitek odehrávat. Dewey to charakterizuje např́klad na situaci výběru povolání. Pokud se někdo rozhodne být lékařem, nutně si tím určí okruh budoucích prožitků, zážitků a získaných zkušeností, než kdyby se stal třeba učitelem. Než se však tento člověk rozhodl být lékařem, jeho rozhodnutí předcházely jeho zkušenosti s tímto oborem. Např́iklad jako malé dítě byl zvědavý, jaké nástroje lékaři při své práci používají, zajímal se o fungování lidského těla či chtěl prožívat společenskou prestiž, kterou lékaři bezesporu mají. Tyto zkušenosti v součinnosti s dalšími faktory, především s prostředím, ve kterém člověk žije, poté vedou ke skutečnosti, že se člověk rozhodne být lékařem. Každý člověk získává jednotlivé zkušenosti díky interakci se svým okolím, a pokud mu dávají potřebný význam a smysl, jsou zařazeny podle principu zkušenostního kontinua do jeho zkušenostní struktury. Kvalita získané zkušenosti je př́mo ovlivněná kvalitou zážitků a prožitků. Čím intenzivnějši emoce jedinec při vykonávané činnosti prožije, tím silnější bude pamětová stopa zážitku a tím trvalejší bude výsledná zkušenost a také bude složitější tuto zkušenost „zrekonstruovat“ následujícími zkušenostmi. Dewey zkušenosti připisuje atributy celistvosti, svébytnosti a individuality.

Na zkušenost Dewey nahliží z různých úhlů pohledu. Prvním z nich je zkušenost jako prostředek k lepšímu pochopení prírodních cyklů. Podle Deweyho má i př́ŕroda své zkušenosti, protože prírodní procesy a změny fungují obdobně jako princip zkušenostního kontinua, tj. přírodní procesy na sebe navazují a mají své prŕćčiny a důsledky. Dewey proto přemýšlí o rozdělení zkušenosti na svrchovanou, absolutní (absolute experience), která obsahuje souhrn zkušeností všech živých bytostí na tomto světě, a lidskou zkušenost (human experience). Avšak pouze absolutní zkušenost může být jako jediná neustále dokonalá, na rozdíl od zkušenosti lidské, která je dočasná, plná chyb, omylů, konfliktů a rozporů. Podle Deweyho se však člověk neustále vyvijí především v rozvoji řeči a zpracováním př́rodních materiálů, které jsou klíčové při kultivaci jeho životního

41 Srov. Richard MACKŮ, Metody a principy výchovy zážitkem, in: Volný čas a jeho význam ve výchově, ed. Michal KAPLÁNEK, Praha: Portál, 20017, s. 182.

42 Srov. Ivo JIRÁSEK, Teoretník, Gymnasion 1/2004, s. 14. 
prostředí, ačkoliv za základní a přirozené prostředí považuje prostř̌edí prrírodní, nikoliv uměle vytvořené. Člověk se ze své podstaty snaží dosáhnout kvalitnějších zkušeností a neustále se rozvíjet a zdokonalovat. Lze tedy i u Deweyho pozorovat vliv Darwinova evolucionismu, který Dewey doplňuje tvrzením, že se člověk vyvinul ze zviŕat, a proto některé základní potřeby a prostředky $\mathrm{k}$ jejich uspokojení zdědil právě od nich. $\mathrm{S}$ těmito tezemi souhlasí například Emil Višňovský v knize Štúdie o pragmatizme \& neopragmatizme. ${ }^{43}$

Dále Dewey nahlíží na zkušenost v souvislosti s uměním a kulturou. Kultura je produktem, který není výsledkem úsilí lidí, kteří se nacházejí v prázdnotě ponecháni sami sobě, nýbrž je výsledkem dlouhodobé kumulativní interakce lidí s jejich prostředím. V návaznosti na umění Dewey zavádí pojem estetická zkušenost (aesthetic experience), která vzniká díky novým nápadům, myšlenkám a řešením nově vzniklých problémů. Nejčastěji se estetická zkušenost projevuje v umění. Podle Deweyho umění a umělecká díla představují sjednocení a objasnění předchozích zkušeností. Umělecké dílo lze chápat jako produkt i jako obsah zkušenosti. Dewey poukazuje na vztah mezi zkušeností, uměním a prírodou. Zdůvodňuje to zpracováním př́rodních materiálů a jejich využití a zobrazení právě v umění. Lidé neustále vyrábí a sdílejí předměty a umění, protože jsou společensky užitečné, významné nebo drahocenné. Při jejich výrobě autoři do svých uměleckých děl promítají své zkušenosti. Dewey dodává, že pokud se člověk přizpůsobí svému životnímu prostředí, dostaví se naplnění kulminující v žádoucí pocit štěstí a užitečnosti. Můžeme zde vysledovat Deweyho narážky na utilitarismus. Podle Deweyho má člověk přirozenou tendenci př́ijemné prožitky vyhledávat a opakovat. Především má na mysli prožitky spojené s tancem, písněmi a hostinami. Člověk má ve své povaze předpoklady $\mathrm{k}$ hledání štěstí a touhu dělat dobré a užitečné věci pro sebe i ostatní.

$\mathrm{V}$ poslední řadě hledí Dewey na zkušenost $\mathrm{z}$ výchovného hlediska. Dewey celkově nahlíží na teorii zkušenostního učení jako na nabídku výběru a organizace vhodných edukativních metod a materiálů potřebných pro nový způsob školní práce. Podle Deweyho je zapotřebí v každé snaze jedince o dosažení určitého cíle rozlišit, které zkušenosti jsou cenné pro výchovu a které nikoliv. Podle Deweyho je to základní kritérium zkušenosti. Zkušenosti působí kladně nebo záporně na postoje člověka, kterému pomáhají posoudit kvalitu dalších zážitků vyzdvižením jistých preferencí a averzí, a usnadňují nebo znesnadňují jednání. Dewey hovoří o zkušenosti ve spojení s žákem a obsahem edukace. Dítě si nové zkušenosti ukládá do jednotné zkušeností struktury, ve které má uloženy všechny své dosavadní informace o světě. Tato zkušenostní struktura má charakter osobních i společenských zájmů, které život přináší. Dewey však kritizuje, že ve škole jsou dítěti nové poznatky přednášeny odděleně, ve zlomcích, a navíc často v abstraktních pojmech či souvislostech. Učební osnovy se musí protnout se zájmy dítěte podle jeho podmínek. Měly by dát dítěti př́ležitost prozkoumat, prožít a zhodnotit vykonané činnosti, a tím propojit důležité informace vedoucí k osvojení i abstraktních principů. Dewey podotýká, že je nezbytné rozšíritit rozsah zkušeností dítěte. Zkušenost dítěte není konečná, nýbrž je přechodná a tvarovatelná. Deweyho teorie zkušenostního učení je také zaměřena na výchovu k ideální demokratické společnosti. Společnost se neustále vyvíjí a je potřeba na tyto změny reagovat. Žáci prostřednictvím učení ze zkušeností modifikují své jednání na základě předchozích zkušeností a lépe rozvíjejí dispozice, které jim budou prospěšné při řešení podobného problému v budoucnosti. Následující zkušenost doplňuje zkušenost již získanou a objasňuje v ní obsažené vztahy. Pozdějš́ činnost tak upevňuje a doplňuje smysl dř́ivější činnosti.

Dewey vyzdvihuje tvrzení, že rekonstrukce zkušenosti může být sociální i individuální.

43 Srov. Emil VIŠŇOVSKÝ, Štúdie o pragmatizme \& neopragmatizme, Bratislava: Slovenská akademie věd, 2009, s. 116-117. 
V tradičních a statických společnostech je výchova procesem, v němž dítě přijímá postoje a kulturní bohatství dospělých, a to především $\mathrm{z}$ důvodu zachování zavedených zvyků a hodnot. Avšak v progresivní společnosti je tomu jinak. Zde se výchovou společnost snaží utvářet zkušenosti mládeže tak, aby se místo pouhé reprodukce běžných zvyklostí utvářely lepší vztahy, a aby tak budoucí společnost byla lepší než ta současná. Dewey kritizuje jakoukoli výchovnou koncepci, která spočívá pouze a jen $\mathrm{v}$ př́ípravě na budoucí povolání a nebere $\mathrm{v}$ potaz současné žákovy zájmy. Dewey znovu naráží na integrační a socializační funkci školy. Škola klade důraz na adaptaci dítěte na širší sociální prostředí a na jeho osamostatnění od rodičů a sourozenců, které Dewey chápe jako primární společenskou skupinu, do které se dítě narodilo. Dnes můžeme sledovat uplatnění principů $\mathrm{z}$ Deweyho teorie zkušenostního učení například v zážitkové pedagogice. Zážitková pedagogika (také zážitkové vzdělávání nebo výchova zážitkem) je přístup ke vzdělávání založený na schopnosti lidské paměti vstřebávat informace, jejichž vnímání je provázeno intenzivní emocí. Jde o učení $z$ důsledků vlastního jednání, hledání netradičních řešení a společné překonávání úkolů a výzev. Předností zážitkového vzdělávání je rozvíjení tvůrčích postupů, aktivní jednání, lepší vytváření neformálních vztahů jedince ve skupině, a především intenzivní učení ze zážitků namísto pouhého shromaždování informací. Zážitková pedagogika pracuje se zážitkem jako prostředkem k ovlivňování klienta. Směr tohoto ovlivňování je určen pedagogickým cílem. Práce zážitkového pedagoga spočivá v záměrném vytváření situací, v nichž předpokládá intenzivní prožívání, a následné pedagogické práci s těmito zážitky. ${ }^{44}$

\section{Kontakt}

\section{Mgr. Pavel Votava}

Jihočeská univerzita v Českých budějovicích

Teologická fakulta, Katedra pedagogiky

Kněžská 8, 37001 České Budějovice

Pafka.Votava@seznam.cz 